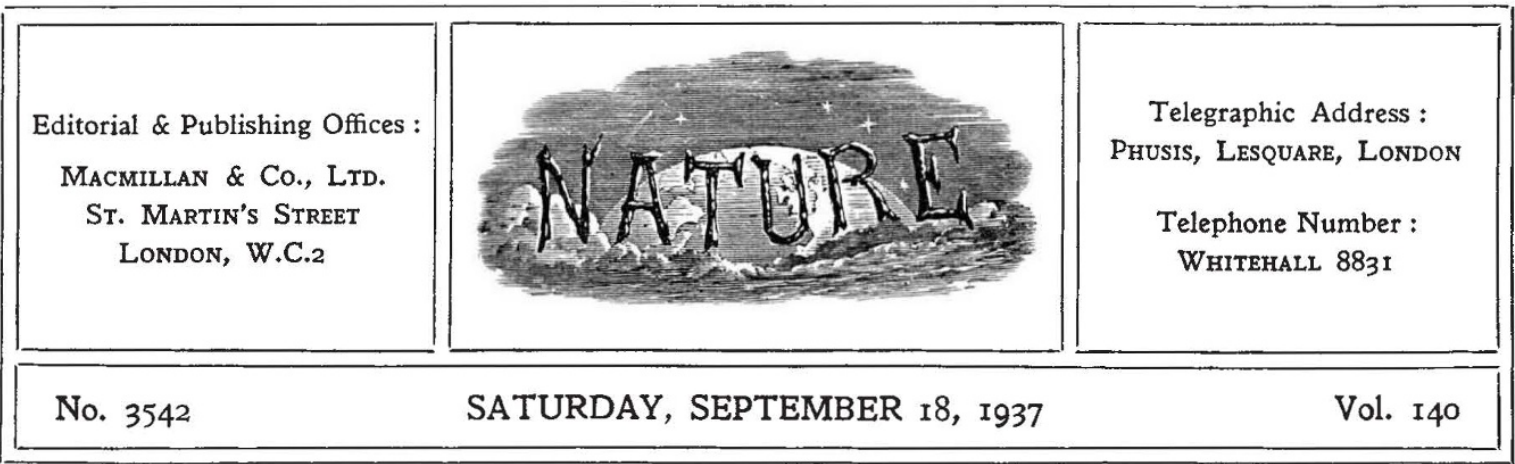

\title{
Philosophy of Early Education
}

$\mathrm{I}^{\mathrm{T}}$ was a foregone conclusion that so original and stimulating a contributor to contemporary thought as Mr. H. G. Wells-on this occasion we are almost invited to dub him Dr. H. G. Wellswould have things to say to Section $\mathrm{L}$ (Education) of the British Association calculated to provoke lively interest and discussion. Few listeners to his presidential address, many of whom were working teachers, could have adopted the language of Tennyson's "Northern Farmer" : "An' I thowt a said whot a owt to 'a said, an' I coom'd awaäy". The address was probably the better for being plain-spoken and provocative, for only so could Mr. Wells have been at his characteristic best.

Notwithstanding certain of his earlier experiences, Mr. Wells disclaimed the right to appear before his audience as a teacher, but preferred to introduce himself as a citizen at large. We take this to mean, what is indeed sufficiently obvious, that he is no expert in the art of teaching a class and managing a school, but that he claims the right of every intelligent citizen to criticize the results of the teaching and the output of the schools. Mr. Wells, however, is something more than a distinguished outsider. In his later phase at least, his writings have been those of a public teacher, who definitely sets out to show what young people ought to learn, if they are to become efficient citizens in the world of to-day. In other words, though he makes only a limited claim to talk about methods of teaching, he makes, rightly as we believe, an emphatic claim to talk about the content of teaching, the mental fare which the schools provide for potential citizens. His now famous "Outline of History", followed by the companion outline of "The Science of Life"-both of them necessarily written with much collaboration -indicated his general view as to the kind of thing which an educated person ought to know. An acquaintance with the fifteenth chapter of his later book, "The Work, Wealth and Happiness of Mankind", further prepared one for the opinions to which he has now given full and forcible expression.

Mr. Wells began and ended his discourse with an almost solemn warning as to his self-imposed limitations. Questions of "drill, skills, art, music, the teaching of languages, mathematics and other symbols, physical training and development, and the rest", he deliberately placed outside the scope of his message. He felt he could be most helpful by concentrating on the sort of world picture we are presenting to young people, the essential framework of knowledge that should be estab. lished betimes in the normal citizen of our modern community. Whether he was fundamentally right in making all these exclusions from the essential framework is bound to be a sharply controversial topic, upon which we cannot fully enter. Suffice it to say that, according to Mr. Wells's judgment of educational values, the indispensable and irreplaceable structure of fact, the main beams and girders of which structure must be laid down, soundly or unsoundly, before the close of adolescence, should rest upon a threefold foundation of history, biology and geography, widely interpreted. These three, says Mr. Wells in effect, are the things that abide, and it is probably safe to add that in his view the greatest of these is history. But merely to quote these familiar labels would be to convey a totally inadequate idea of the length and breadth of his message.

What Mr. Wells means by history was already familiar to many, we hope to most, of his listeners. But he took the opportunity of denouncing once 
more the sort of history which, at any rate until recently, has been taught in our schools, and in great measure accounts for that "crazy combative patriotism" which now threatens to destroy our civilization. Equally mischievous, he added, is the "furtive anti-patriotism of the leftish teacher" We suggest, however, that if Mr. Wells thinks that the sort of history denounced long ago by Herbert Spencer as "an obituary of kings and queens" and denounced later by John Richard Green as "drumand-trumpet history", is still encouraged in our schools, he ought to make further inquiries. But the rest of his indictment is not so easily disposed of. He demands that school history should not only shed its insularity, its narrow nationalism and its contempt for the lesser breeds without the law, but that it should also be nothing less than the story of man's great adventure upon this planet. He claims that the archæologists, and the historians of the rise and fall of empires, have provided far finer material for the mental equipment of modern youth than the 'hole-and-corner' history of a single nation. Here he will have many sym. pathizers and some severe critics. It was to be expected that this part of his address would receive special comment in the daily Press.

As regards the rest of the informative content of the curriculum as conceived by Mr. Wells, there will be general agreement with his ideas about the teaching of geography and simple economics; and indeed the modern teacher in schools of every kind has already gone a long way towards satisfying his requirements. The chanting of lists of capes and rivers is mostly a thing of the past. Where geography passes over into biology his strictures are just. Too many young people leave school ignorant of the wonderful story of life upon the earth, and equally ignorant of the working of their own bodies. But, asks Mr. Wells in effect, who is sufficient for these things? Certainly not, he declares, the present generation of teachers, two-thirds of whom ought to be reconditioned or superannuated. Here again, having regard to the work done in summer schools and refresher courses, and the activities and publications of such large and important professional bodies as the Science Masters' Association and the Geographical Association, Mr. Wells should have made further inquiries. Also even a cursory examination of the text-books or reading-books now available for pupils of all ages, and exhibited by publishers at such meetings as those of the Annual Conference of Educational Associations, would have shown him that the school books of to-day are vastly superior in every respect to those of the past.

The present position is that teachers as a body are more mentally alert and educationally active than ever they were. True, they may not be sufficiently intent upon the informative components of the curriculum as advocated by Mr. Wells, but their general attitude suggests plenty of room for hope. A generation ago, teachers were too much occupied in fighting for reasonable conditions of service. To a great extent they are now occupied in fighting for a better chance for the pupils.

But we wish to close these comments upon a note of appreciation. In one of his charming and vigorous philosophical essays, William James took up strongly the position that the great philosophic thinkers, however much they might try to sink the fact of temperament, could never succeed in doing so. The philosopher's temperament, declared James, "really gives him a stronger bias than any of his more strictly objective premises. It loads the evidence for him one way or the other, making for a more sentimental or a more hardheaded view of the universe". James proceeded to a broad classification of the great philosophic thinkers as the tender-minded and the tough. minded. The tender-minded he described as rationalistic (devoted to abstract and eternal principles), idealistic, optimistic, religious, freewillist and dogmatic. The tough-minded he described as empiricist (devoted to facts in all their crude variety), materialistic, pessimistic, irreligious, fatalistic and sceptical.

Not for one moment would we wish to apply to Mr. Wells every item in the second of these lists of adjectives. But he is one of the outstanding public teachers of our time, accustomed to take the broad philosophic outlook upon every problem that he touches; and if we were asked in which of the two categories we would place him, we should inevitably place him among the tough-minded. Few of our prominent thinkers could, for example, have got to the end of any sort of discourse on education without ever mentioning Shakespeare; but Mr. Wells forgot even to mention literature among the skills, etc., which he designedly excluded from his survey. Perhaps the British Association will next year seek to restore the balance by inviting one of the tender-minded brotherhood to address the Education Section. Meantime, the tough-minded Mr. Wells has given to all interested in education, something to think about and something to follow up. 